\title{
Peningkatan Pembelajaran Materi Cerita Fiksi di Sekolah Dasar melalui Model Numbered Heads Together Dengan Media Audio
}

\section{Oky Kurniawan}

SD Negeri Mandala 02

kukurniawanoky@gmail.com

Article History

received $3 / 12 / 2020$

revised 17/12/2020

accepted $31 / 12 / 2020$

\begin{abstract}
The learning outcomes of fiction story material for 4th graders of Mandala 02 State Elementary School (SDN) Cimanggu District, Cilacap Regency were still low. The researcher applied the numbered heads together (NHT) learning model with audio as a media. This study used a Classroom Action Research (CAR) that designed in two cycles. The results showed that their average value of the class during the pre-test was 52.65, increased in the post-test results to 79.28 with an increase in classical learning completeness from $21.88 \%$ to $88.57 \%$. Student learning activities in the first cycle of $73.91 \%$ increased in the second cycle to $77.76 \%$. The teacher's performance score had reached the indicator of success with the final score in the first cycle of 82.5 increasing in the second cycle to 84.25. The application of the NHT learning model with audio media could improve Indonesian learning of fiction story material.
\end{abstract}

Keywords: Indonesian Language, numbered heads together, audio media, elementary school students

\begin{abstract}
Abstrak
Hasil belajar materi cerita fiksi siswa kelas 4 Sekolah Dasar Negeri (SDN) Mandala 02 Kecamatan Cimanggu Kabupaten Cilacap masih rendah. Peneliti menerapkan model pembelajaran numbered heads together (NHT) dengan media audio. Penelitian ini menggunakan rancangan Penelitian Tindakan Kelas (PTK) dalam dua siklus. Hasil penelitian menunjukan nilai rata-rata kelas saat pelaksanaan pre test sebesar 52,65 meningkat pada hasil post test menjadi 79,28 dengan peningkatan ketuntasan belajar klasikal dari 21,88 \% menjadi $88,57 \%$. Aktivitas belajar siswa pada siklus I sebesar $73,91 \%$ meningkat pada siklus II menjadi $77,76 \%$. Perolehan nilai performansi guru telah mencapai indikator keberhasilan dengan perolehan nilai akhir pada siklus I sebesar 82,5 meningkat pada siklus II menjadi 84,25. Penerapan model pembelajaran NHT dengan media audio dapat meningkatkan pembelajaran Bahasa Indonesia materi cerita fiksi.
\end{abstract}

Kata kunci: Bahasa Indonesia, numbered heads together, media audio, siswa sekolah dasar

Social, Humanities, and Education Studies (SHEs): Conference Series

p-ISSN 2620-9284 https://jurnal.uns.ac.id/shes e-ISSN 2620-9292 


\section{PENDAHULUAN}

Dalam kurikulum 2013 kegiatan pembelajaran di Sekolah Dasar kelas I sampai kelas VI dilakukan dengan menggunakan pembelajaran tematik terpadu yang memadukan beberapa materi pembelajaran dari berbagai standar kompetensi dan kompetensi dasar dari satu atau beberapa mata pelajaran. Pembelajaran tematik terpadu adalah pembelajaran yang dikemas dalam bentuk tema-tema berdasarkan muatan beberapa mata pelajaran yang dipadukan atau diintegrasikan (Rusman, 2015:139). Kurikulum 2013 menekankan pada peserta didik untuk aktif dan kreatif selama proses pembelajaran berlangsung sehingga hasil belajar yang didapat diharapkan akan lebih optimal.

Pada kenyataannya, menurut pengamatan peneliti masih banyak siswa yang hasil belajarnya tidak optimal. Hal itu dikarenakan siswa kesulitan dalam mempelajari materi-materi pelajaran, salah satunya materi muatan pelajaran Bahasa Indonesia. Hal ini juga terjadi dalam pelaksanaan pembelajaran di kelas 4 Sekolah Dasar Negeri Mandala 2 (SDN Mandala 02) Kecamatan Cimanggu Kabupaten Cilacap, materi cerita fiksi. Siswa masih kesulitan dalam mempelajari materi tersebut. Diketahui pula bahwa nilai tes formatif materi cerita fiksi kelas 4 tahun pelajaran 2019/2020 belum mencapai kriteria ketuntasan minimum (KKM). Berdasarkan data tersebut, perlunya suatu model pembelajaran yang lebih efektif dan sesuai dengan karakteristik siswa SD untuk meningkatkan aktivitas dan hasil belajar materi cerita fiksi.

Kegiatan belajar siswa dapat ditingkatkan melalui proses berpikir yang dibarengi dengan interaksi sosial. Salah satu model pembelajaran yang memberikan kesempatan kepada siswa untuk berinteraksi sosial adalah model pembelajaran cooperative learning. Model pembelajaran kooperatif adalah model pembelajaran yang melibatkan partisipasi siswa dalam kelompok kecil yang setiap anggotanya bertanggungjawab atas dirinya sendiri dan orang lain untuk memahami materi yang dipelajari (A. Majid, 2015; Suwarto, 2014).

Terdapat beberapa pembelajaran kooperatif, diantaranya model pembelajaran think pair share (TPS), two stay two stray (TSTS) dan numbered heads togther (NHT). Masing-masing model memiliki karakteristik yang berbeda. Numbered Heads Together (NHT) merupakan salah satu model pembelajaran kooperatif yang dikembangkan oleh Spenser Kagan pada tahun 1993 (Ratumanan, 2015). Langkah-langkah model pembelajaran NHT diantaranya sebagai berikut : (Nugrahaeni, 2012)

a. Langkah 1

Siswa dibagi dalam kelompok, setiap siswa dalam kelompok mendapatkan nomor

b. Langkah 2

Guru memberikan tugas pada masing-masing kelompok, kemudian kelompok samasama mengerjakannya

c. Langkah 3

Kelompok memutuskan jawaban yang dianggap paling benar dan memastikan setiap anggota mengetahui jawabannya

d. Langkah 4

Guru memanggil salah satu nomor, siswa dengan nomor yang dipanggil melaporkan hasil kerjasama mereka

Dengan model NHT siswa menjadi lebih aktif, kreatif, disiplin dan bertanggung jawab terhadap tugas yang diberikan guru(Iskandar, A. P., \& Leonard, L, 2018). Tipe NHT memberi kesempatan kepada peserta didik untuk saling berbagi ide, saran, dan pertimbangan untuk menemukan jawaban yang paling tepat atas pertanyaan yang diberikan guru, serta meningkatkan kerjasama di antara mereka (Isjoni, 2013:113)

Pengunaan model penelitian Numbered Heads Together (NHT) pernah dibuktikan oleh Dian Anggraini (2019) dan Birillina (2019). Dian Anggraini membuktikan bahwa NHT berpengaruh untuk meningkatkan keterampilan menentukan gagasan 
pokok. Sedangkan Birillina dalam penelitiannya membuktikan bahwa penggunaan model pembelajaran NHT meningkatkan kemampuan pemecahan masalah materi operasi hitung perkalian dan pembagian peserta didik.

Selain penggunaan model NHT, peneliti juga akan menggunakan media audio. Media audio adalah bahan yang mengandung pesan dalam bentuk auditif (pita suara atau piringan hitam), yang dapat merangsang pikiran, perasaan, perhatian, dan kemauan siswa, sehingga terjadi pembelajaran (Ramli, 2012: 76)

Berdasarkan uraian di atas, peneliti terinspirasi untuk mengadakan penelitian tindakan kelas (PTK) yang berjudul " Penggunaan Model Pembelajaran Numbered Heads Together dengan media audio dalam Meningkatkan Aktivitas dan Hasil Belajar Cerita Fiksi pada Siswa Kelas 5 SD Negeri Mandala 02".

\section{METODE}

Penelitian ini menggunakan metode Penelitian Tindakan Kelas (PTK). Penelitian Tindakan Kelas merupakan suatu pencermatan terhadap kegiatan belajar berupa sebuah tindakan yang sengaja dimunculkan dan terjadi dalam sebuah kelas secara bersamaan (Arikunto, 2014: 2-3). Dalam penelitian ini menggunakan model penelitian yang merujuk pada proses pelaksanaan penelitian yang dikemukakan oleh Kemmis dan Mc Taggart (1988) (dalam Mu'alimin, 2014: 17), penelitian ini dalam perencanaannya, Kemmis menggunakan sistem spiral refleksi diri yang dimulai dengan: (1) Rencana (planning), (2) Tindakan (acting), (3) Pengamatan (observing), (4) Refleksi (reflecting), dan perencanaan kembali yang merupakan dasar untuk suatu ancang-ancang pemecahan permasalahan. Penelitian ini dilaksanakan dalam dua siklus. Setiap siklus terdiri dari 2 pertemuan dan setiap akhir pelaksanaan siklus diadakan tes sumatif. Sebelum tindakan, diadakan pre test terlebih dahulu. Penelitian terlaksana pada Januari sampai Maret 2020 di kelas IV SD Negeri Mandala 02. Subjek penelitian yaitu guru dan siswa kelas IV SD Negeri Mandala 02. Siswa kelas IV berjumlah 35 yang terdiri dari 21 perempuan dan 14 laki-laki. Teknik pengumpulan data terdiri dari tes dan non tes. Tes dalam penelitian ini terdiri dari pre test dan tes formatif. Dalam teknik non tes digunakan teknik observasi (aktivitas siswa dan performasi guru). Model pembelajaran NHT dengan media audio dikatakan dapat meningkatkan aktivitas dan hasil belajar siswa serta performasi guru jika, nilai ratarata kelas $\geq 65$, percentase tuntas klasikal $\geq 75 \%$, dan tuntas individu $\geq 65$ sesuai KKM yang telah ditentukan, aktivitas belajar siswa kehadiran siswa minimal $75 \%$ dan keaktifan belajar siswa minimal 75\%, serta nilai APKG I dan APKG II minimal B (>7080).

\section{HASIL DAN PEMBAHASAN}

Penyajian data hasil penelitian mengenai perkembangan materi cerita fiksi terdapat tiga, Yaitu : pratindakan, siklus 1 dan siklus 2. Pada awalnya penguasaan materi cerita fiksi rendah. Hal tersebut diperoleh dari hasil pre test. Ringkasan hasil pre test dapat dilihat dalam Tabel 1.

Tabel 1. Data hasil pre test

\begin{tabular}{llccccc} 
No & Kategori & Nilai & $\mathbf{f}$ & Jumlah & $\%$ & Rata-rata \\
\hline 1 & Sangat Baik & $85-100$ & 0 & 0 & $0 \%$ & $\frac{1685}{32}$ \\
2 & Baik & $75-84$ & 2 & 150 & $6,3 \%$ & $=52,65$ \\
3 & Cukup & $65-74$ & 5 & 335 & $15,6 \%$ & $=52,65$ \\
4 & Kurang & $0-64$ & 25 & 1200 & $78,1 \%$ & \\
\hline & & 32 & 1685 & $100 \%$ & \\
\hline
\end{tabular}


Tabel 1 menunjukkan bahwa nilai rata-rata kelas yaitu 52,65. Nilai rerata tersebut masih di bawah KKM yang telah ditentukan. Ketuntasan belajar klasikalnya juga belum mencapai $75 \%$. Ada 3 siswa yang tidak mengikuti pre test. Penelitian dilanjutkan pada siklus 1 menggunakan model pembelajaran NHT dengan media audio dengan hasil tabel 2.

Tabel 2. Rangkuman hasil belajar siswa pada siklus 1

\begin{tabular}{llccccc}
\hline No & Kategori & Nilai & f & Jumlah & $\%$ & Rata-rata \\
\hline 1 & Sangat Baik & $85-100$ & 4 & 373 & $12,12 \%$ & $\frac{2234}{33}$ \\
2 & Baik & $75-84$ & 6 & 470 & $18,18 \%$ & 33 \\
3 & Cukup & $65-74$ & 13 & 874 & $39,39 \%$ & $=67,69$ \\
4 & Kurang & $0-64$ & 10 & 517 & $30,31 \%$ & \\
\hline & & 33 & & $100 \%$ & \\
\hline
\end{tabular}

Tabel 2 menunjukkan nilai rata-rata kelas pada siklus 1 adalah 67,69, itu artinya nilai rata-rata nilai siklus 1 sudah memenuhi KKM mata pelajaran Bahasa Indonesia semester 2 SDN Negeri Mandala 02 yaitu 65. Ketuntasan belajar klasikal belum mencapai 75\%. Data observasi aktivitas siswa siklus 1 dapat dilihat di tabel 3.

Tabel 3 Ringkasan hasil observasi aktivitas siswa

\begin{tabular}{|c|c|c|c|c|c|}
\hline \multirow{2}{*}{ No } & \multirow{2}{*}{ Rentang Skor } & \multicolumn{2}{|c|}{ Pertemuan 1} & \multicolumn{2}{|c|}{ Pertemuan 2} \\
\hline & & Frekuensi & Jumlah skor & Frekuensi & Jumlah skor \\
\hline 1 & $16-20$ & 7 & 118 & 12 & 197 \\
\hline 2 & $11-15$ & 28 & 354 & 21 & 308 \\
\hline 3 & $6-10$ & 0 & 0 & 0 & 0 \\
\hline 4 & $1-5$ & 0 & 0 & 0 & 0 \\
\hline \multicolumn{2}{|c|}{ Jumlah } & 35 & 499 & 33 & 505 \\
\hline \multicolumn{2}{|c|}{$\begin{array}{l}\text { Persentase } \\
\text { Siswa (PAS) }\end{array}$} & tas $\frac{499}{700} \times 10$ & $\%=71,29 \%$ & \multicolumn{2}{|c|}{$\frac{505}{660} \times 100 \%=76,52 \%$} \\
\hline \multicolumn{2}{|c|}{ PAS siklus 1} & $\frac{P A S 1+}{2}$ & PAS2 $=\underline{71,29}$ & \multicolumn{2}{|c|}{$\frac{+76,52 \%}{2}=73,91 \%$} \\
\hline
\end{tabular}

Tabel 3 menunjukan bahwa persentase aktivitas siswa (PAS) pada siklus I peertemuan 1 yakni $71,29 \%$ dan pada pertemuan 2 yakni 76,52\%.Rata-rata PAS siklus 1 sebesar 73,91\%. Berdasarkan data tersebut menunjukan bahwa PAS pada siklus 1 belum mencapai indikator yang telah ditentukan yakni PAS $\geq 75 \%$. Data performansi guru siklus 1 di tabel 4

Tabel 4. Hasil observasi performansi guru pada siklus 1

\begin{tabular}{|c|c|c|c|c|c|c|}
\hline No & Aspek penilaian & \multicolumn{2}{|c|}{ Nilai } & $\begin{array}{l}\text { Rata- } \\
\text { rata }\end{array}$ & Bobot & Jumlah \\
\hline 1 & Kemampuan guru & \multirow{2}{*}{\multicolumn{2}{|c|}{81,25}} & & & \\
\hline \multirow[b]{2}{*}{2} & $\begin{array}{l}\text { dalam menyusun } \\
\text { RPP }\end{array}$ & & & 81,25 & 1 & 81,25 \\
\hline & $\begin{array}{l}\text { Kemampuan guru } \\
\text { dalam pelaksanaan } \\
\text { pembelajaran }\end{array}$ & 82,5 & 83,75 & 83,125 & 2 & 166,25 \\
\hline \multicolumn{2}{|c|}{ Jumlah } & & & & 3 & 247,5 \\
\hline \multicolumn{2}{|c|}{ Nilai akhir } & & & & & 82,5 \\
\hline \multicolumn{2}{|c|}{ Kriteria } & & & & & $A B$ \\
\hline
\end{tabular}

Berdasarkan tabel 4 nilai akhir dari performansi guru pada siklus 1 yaitu 82,5. Data performansi guru ini sudah mencapai indikator keberhasilan yang telah ditetapkan yakni $\geq 71$ (B). Tabel 5 adalah data hasil belajar siswa siklus 2 
SHEs: Conference Series 3 (4) (2020) $201-207$

Tabel 5. Ringkasan hasil belajar siklus II

\begin{tabular}{clccccc}
\hline No & Kategori & Nilai & f & Jumlah & $\%$ & Rata-rata \\
\hline 1 & Sangat Baik & $85-100$ & 13 & 1245 & $37,14 \%$ & $\frac{2775}{35}$ \\
2 & Baik & $75-84$ & 5 & 395 & $14,29 \%$ & 35 \\
3 & Cukup & $65-74$ & 13 & 895 & $37,14 \%$ & $=79,28$ \\
4 & Kurang & $0-64$ & 4 & 240 & $11,43 \%$ & \\
\hline \multicolumn{2}{c}{ Jumlah } & & 35 & 2775 & $100 \%$ & \\
\hline
\end{tabular}

Merujuk pada tabel 5. Siklus II memiliki rata-rata 79,28 termasuk dalam kategori baik. Terdapat 13 siswa atau sebesar $37,14 \%$ yang mencapai nilai salam kategori sangat baik. Siswa yang memperoleh nilai antara 0-64 berjumlah 4 siswa atau 11,43\%. Siklus II ketuntasan klasikal $88,47 \%$ dan sudah mencapai kinerja penelitian yaitu $75 \%$. Sehingga pada siklus II penelitian dihentikan.

Tabel 6. Ringkasan hasil observasi aktivitas siswa pada siklus II

\begin{tabular}{|c|c|c|c|c|c|}
\hline \multirow[b]{2}{*}{ No } & \multirow[b]{2}{*}{ Rentang skor } & \multicolumn{2}{|c|}{ Pertemuan 1} & \multicolumn{2}{|c|}{ Pertemuan 2} \\
\hline & & Frekuensi & $\begin{array}{l}\text { Jumlah } \\
\text { skor }\end{array}$ & Frekuensi & Jumlah skor \\
\hline 1 & $16-20$ & 13 & 217 & 19 & 232 \\
\hline 2 & $11-15$ & 22 & 312 & 16 & 327 \\
\hline 3 & $6-10$ & 0 & 0 & 0 & 0 \\
\hline 4 & $1-5$ & 0 & 0 & 0 & 0 \\
\hline \multicolumn{2}{|c|}{ Jumlah } & 35 & 529 & 35 & 559 \\
\hline \multicolumn{2}{|c|}{$\begin{array}{l}\text { Persentase aktivitas } \\
\text { siswa }\end{array}$} & $\frac{529}{700} \times 100 \%$ & $5,57 \%$ & \multicolumn{2}{|c|}{$\frac{559}{700} \times 100 \%=79,86 \%$} \\
\hline \multicolumn{2}{|c|}{ PAS siklus II } & $\frac{P A S 1+P A S}{2}$ & $75,57 \%$ & \multicolumn{2}{|c|}{$79,86 \%=77,72 \%$} \\
\hline
\end{tabular}

Tabel 6 menunjukan bahwa persentase aktivitas siswa (PAS) pada siklus 2 pertemuan 1 yakni $75,57 \%$ dan pertemuan 2 yakni $79,86 \%$. Rata-rata persentase PAS siklus II yaitu $77,72 \%$. Hal tersebut menunjukan pembelajaran sudah berhasil karena telah mencapai indikator persentase aktivitas siswa yakni $\geq 75 \%$. Untuk ringkasan hasil observasi performansi guru siklus II di tabel 7.

Tabel 7. Hasil observassi performansi guru pada siklus II

\begin{tabular}{|c|c|c|c|c|c|c|}
\hline \multirow{2}{*}{ No } & \multirow{2}{*}{ Aspek penilaian } & \multicolumn{2}{|c|}{ Nilai } & \multirow{2}{*}{$\begin{array}{l}\text { Rata- } \\
\text { rata } \\
2\end{array}$} & \multirow[t]{2}{*}{ Bobot } & \multirow[t]{2}{*}{ Jumlah } \\
\hline & & Pertemuan 1 & Pertemuan 2 & & & \\
\hline 1 & $\begin{array}{l}\text { Kemampuan guru } \\
\text { dalam menyusun } \\
\text { RPP }\end{array}$ & 84 & & 84 & 1 & 84 \\
\hline 2 & $\begin{array}{l}\text { Kemampuan guru } \\
\text { dalam } \\
\text { melaksanakan } \\
\text { pembelajaran }\end{array}$ & 84 & 84,75 & 84,375 & 2 & 168,75 \\
\hline \multicolumn{2}{|c|}{ Jumlah } & & & & 3 & 252,75 \\
\hline \multicolumn{2}{|c|}{ Nilai akhir } & & & & & 84,25 \\
\hline \multicolumn{2}{|c|}{ Kriteria } & & & & & $A B$ \\
\hline
\end{tabular}

Berdasarkan tabel 7 nilai akhir performansi guru yaitu 84,25 dengan kriteria $A B$. Data tersebut menunjukan performansi guru sudah mencapai indikator keberhasilan yang telah ditetapkan yakni $\geq 71$ (B). Peningkatan hasil belajar, ketuntasan belajar klasikal, aktivitas siswa dan performansi guru dapat dilihat pada gambar 1 di bawah ini: 
SHEs: Conference Series 3 (4) (2020) $201-207$

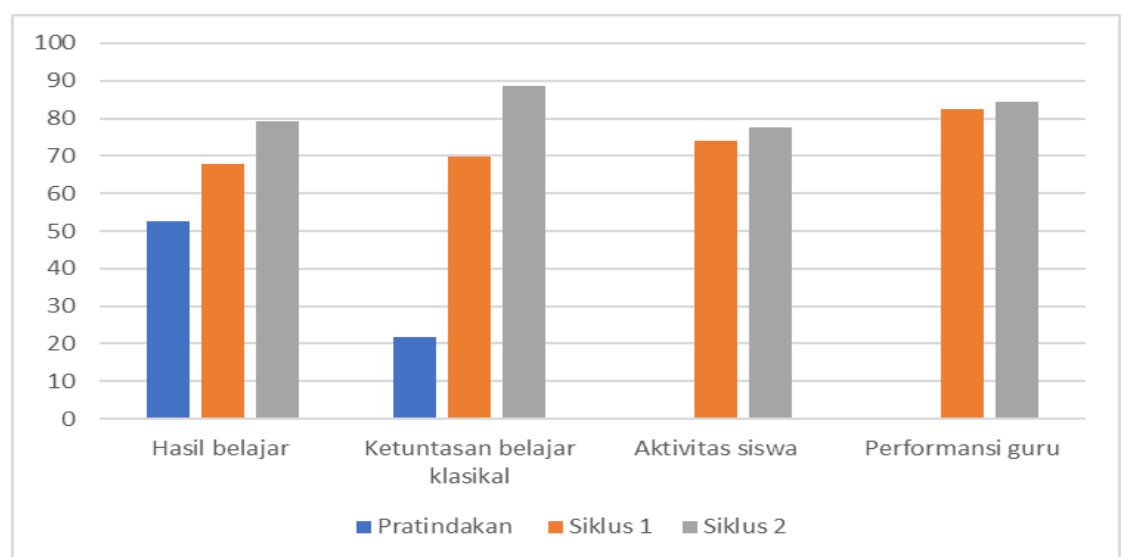

Gambar 1. Perbandingan peningkatan pelaksanaan tindakan pembelajaran

Bersumber dari gambar 1 terlihat bahwa terjadi peningkatan dari pratindakan hingga siklus II. Rata-rata nilai pratindakan sebesar 52,65 kemudian meningkat pada siklus I menjadi 67,69, dan meningkat lagi pada siklus II menjadi 83. Peningkatan hasil belajar siswa yang terjadi menunjukkan bahwa siswa telah mengalami peningkatan keterampilan karena telah melalui tahap belajar. Hal ini sejalan dengan pengertian belajar dari Dictionary of Psychology ini menekankan aspek proses serta keadaan sebagai hasil belajar (Sriyanti, 2011:16-17). Presentase ketuntasan klasikal pada pratindakan diperroleh sebesar 21,9\%, meningkat pada siklus I menjadi $69,69 \%$, dan pada siklus II ketuntasan bertambah menjadi $88,57 \%$. Kenaikan juga terjadi diaspek aktivitas siswa pada siklus I $73,91 \%$ bertambah menjadi $77,72 \%$ di siklus II. Peningkatan keaktifan siswa dari siklus I ke siklus II juga menunjukkan siswa telah mengalami proses belajar. Keaktifan siswa yang tinggi ini dikarenakan pembelajaran kooperatif menuntut suatu kelompok siswa bekerja untuk menyelesaikan tugas yang sama. Performansi guru juga meningkat. Indikator kinerja penelitian sudah tercapai.

Penerapan model pembelajaran Numbered Head Together (NHT) dengan media audio dinyatakan dapat meningkatkan aktivitas dan hasil belajar cerita fiksi pada siswa kelas IV SD Negeri Mandala 02 Tahun ajaran 2019/2020. Dapat dibuktikan dengan data-data yang dipaparkan di atas. Peningkatan yang terjadi pada setiap siklus merupakan bukti keefektifan model pembelajaran Numbered Head Together (NHT) dengan media audio yang telah diterapkan. Temuan pada penelitian ini relevan dengan penelitian Hildayanti Anwar (2014) dan Vina Kristanti (2011). Dalam penelitiannya Hildayanti Anwar membuktikan bahwa penggunaan model pembelajaran NHT meningkatkan hasil belajar siswa pada pokok bahasan gaya kelas V SDN 6 Tambun, sedangkan Vina Kristanti menggunakan media audio untuk meningkatkan ketrampilan identifikasi unsur-unsur cerita anak.

Merujuk ulasan di atas, diketahui model Numbered Head Together (NHT) dengan media audio mampu mengatasi masalah dalam PTK ini. Dibuktikan dengan hasil data yang diperoleh bahwa ada peningkatan presentase ketercapaian di setiap siklusnya. Maka dari itu, dapat dikatakan bahwa penerapan model Numbered Head Together (NHT) dengan media audio dapat meningkatkan aktivitas dan hasil belajar cerita fiksi pada siswa

\section{SIMPULAN}

Berdasarkan hasil penelitian dan pembahasan maka dapat disimpulkan Numbered Head Together (NHT) dengan media audio meningkatkan aktivitas dan hasil belajar cerita fiksi pada siswa kelas IV SD Negeri Mandala 02. Adapun rincian peningkatan sebagai berikut: 
Nilai rata-rata kelas saat pre test adalah 52,65 meningkat menjadi 67,69 di siklus I dan meningkat lagi di siklus II menjadi 79,28. Ketuntasan belajar klasikal juga meningkat dari $21,9 \%$ saat pre test menjadi $69,69 \%$ di siklus I dan $88,57 \%$ di siklus II. Aktivitas belajar siswa pada siklus I yaitu $73,91 \%$ mengalami peningkatan pada siklus II menjadi $77,72 \%$, aktivitas belajar pada siklus II maupun siklus II telah mencapai kriteria aktif. Sedangkan perolehan nilai performansi guru telah mencapai indikator keberhasilan dengan perolehan nilai akhir pada siklus I mencapai 82,5 dan meningkat pada siklus II menjadi 84,25. Implikasi teoritis penelitian ini adalah mampu dijadikan rujukan penelitian lain yang sejenis mengenai model pembelajaran Numbered Head Together (NHT) dengan media audio. Sedangkan implikasi praktis penelitian ini bagi mata pelajaran Bahasa Indonesia adalah mampu dijadikan upaya alternatif guru mengenai model pembelajaran Numbered Head Together (NHT) dengan media audio untuk meningkatkan kualitas pembelajaran khususnya mata pelajaran Bahasa Indonesia.

\section{DAFTAR PUSTAKA}

Anggraeni, D. (2019). Penggunaan Model Pembelajaran Kooperatif Tipe Numbered Head Together (NHT) Untuk Meningkatkan Keterampilan Menentukan Gagasan Pokok Siswa Kelas IV Sd Islam Al-Chusnaini Kelopo Sepuluh Sidoarjo. JPGSD. $7(5), 3479-3490$.

Anwar, H. (2014). Upaya Meningkatkan Hasil Belajar Siswa dengan Menggunakan Metode NHT (Numbered Head Together) pada Pokok Bahasan Gaya Kelas V SDN 6 Tambun. Tadulako: Jurnal Kreatif Tadulako Online, 4(10).

Arikunto, Suharsimi, Suhardjono dan Supardi. (2014). Penelitian Tindakan Kelas. Jakarta: PT Bumi Aksara

Isjoni. (2013). Pembelajaran Kooperatif; Meningkatkan Kecerdasan Komunikasi Antar Peserta Didik. Pustaka Pelajar: Yogyakarta

Iskandar, A. P., \& Leonard, L. (2018). Model pembelajaran Numbered Heads Together (NHT) dengan strategi pembelajaran tugas dan paksa. In Seminar Nasional dan Diskusi Panel Multidisiplin Hasil Penelitian dan Pengabdian Kepada Masyarakat 2018, 1(1).

Kristianti, V. (2011). Peningkatan keterampilan mengidentifikasi unsur-unsur cerita anak melalui media audio siswa kelas V SDN Pagerwojo 01 Kabupaten Blitar. Malang: Skripsi Universitas Negeri Malang.

Majid, A. (2015). Strategi Pembelajaran. Bandung: PT Remaja Rosdakarya

Mu'alimin. (2014). Penelitian Tindakan Kelas Teori dan Praktek. Pasuruan: Ganding Pustaka

N Birillina \& Hartatik S .(2019). Pengaruh Model Pembelajaran Numbered Head Together terhadap Kemampuan Pemecahan Masalah dan Hasil Belajar Siswa pada Mata Pelajaran Matematika Materi Operasi Hitung. Perkalian dan Pembagian di Kelas III SD Kemala Bayangkari I Surabaya. MUST: Journal of Mathematics Education, Science and Technology, 4(2), 217.

Nugrahaeni, A.S. (2012). Penerapan Strategi Cooperative Learning Dalam Pembelajaran Bahasa Indonesia.Yogyakarta: PT Pustaka Insan Madani.

Ramli, M. (2012). Media dan Tekhnologi Pembelajaran. Banjarmasin: Antasari Press.

Ratumanan. (2015). Inovasi Pembelajaran. Ombak.

Rusman. (2015). Pembelajaran Tematik Terpadu Teori, Praktik, dan Penilaian. Jakarta: Rajawali Pers

Sriyanti, L. (2011). Psikologi Belajar. Salatiga: STAIN Salatiga Press.

Suwarto. (2014). Model-Model Pembelajaran Berwawasan Lingkungan Hidup. Pelangi Pres

Trianto. (2011). Model-model Pembelajaran Inovatif Berorientasi Kontruktivistik. Jakarta: Prestasi Pustaka Publisher. 